\title{
In What Ways University in Indonesia as World-Class University Can Produce a Global Competitive Human Capital (Case Study: Telkom University)
}

\author{
Dr. Djoko Murdowo, MBA \\ Telkom University, Bandung \\ Indonesia
}

\begin{abstract}
The small number of universities in Indonesia that can be considered as World-Class University (WCU) is due to: bureaucratic university governance, facilities that are still depend on the government subsidies, as well as university management that is not yet professional, autonomous and independent, not to mention the discrimination of policy treatment on private university. This problem should be resolved immediately, considering that in the current global competition era, every country including Indonesia is in desperate need of competent human resources, and it cannot be denied that university is a container that should be able to provide human resources that can directly dive into various work fields. Research methodology used to analyze and solve the problem in this paper is qualitative method with case study approach. Lesson learned from the case study of Telkom University is it is necessary to supervise not only state-owned universities, but also private ones, offering them guidance and support. Private universities should be given equal treatments. The author of this article recommends that a long-term master plan about the number of universities in Indonesia which classified into two types (state university and private university) should be drawn. The management pattern of universities should embrace the concept of "higher education as industry" as practiced in many developed countries. Continuous benchmarking and international cooperation should be made. Academic autonomy should be encouraged. In principle, a big private university, such as Telkom University, that has potential to be WCU, still needs some guidance and assistance.
\end{abstract}

Keywords: World-Class University, Human Capital

\section{Introduction}

One way to develop the future well-being is through investment in human capital. Investing in human capital can be pursued by many ways, such as the provision of quality education, medical care and acquisition of information for economic system (Becker 1962). In recent years, the Indonesian government has pushed both the state-owned universities and private universities in the country to maximize the returns of their investments. In this way, it is hoped that they will be able to compete in the local and global markets. Given the idea of building World-Class Universities (WCU) has become a necessity for Indonesian universities, the concept of WCU has not been truly understood. As pointed out by Peter G. Altbach (2003, p.4) elsewhere as in Indonesia, "Everyone wants a WorldClass University. No country feels it can do without one. The problem is that no one knows what a World-Class University is, and no one has figured out how to get one. Everyone, however, refers to the concept". At best, WCU is commonly understood through the business of rankings made and published by a few organizations such as Shanghai Jia Tong University (SJTU); Times Higher Education (THE); Quacquarelly Symonds (QS); We bometric. What Salmi Jamil (2009, p. 19) has suggested as the "three complementary factors at play" that condition the development of WCU, namely a high concentration of talent, abundant resources and favorable governance, seem to have not found their resonance in Indonesia. Along with this problem, as suggested in the abstract of this article, most Indonesian universities still face many challenges in order to build their reputation both locally and globally. Some of the challenges may not be unique for any universities attempting to aim higher. They are part of the political and cultural variation in World-Class Universities (Marginson, 2012), which will be the focus of discussion in this article. 


\section{Research Methodology}

This research is a qualitative research with case study approach. According to Keirl and Miller in Moleong, qualitative research is "a particular tradition in social science that fundamentally dependent on observation, people, the region itself, and connecting with those people in their language and terminology". This means that the data collected is not a number, but the data comes from interviews, field notes, personal documents, notes, memos, and other official documents. The case study approach focuses intensively on one particular object and examines it as a case. A good case study should be done directly in the actual life of the case under investigation. However, case study data can be obtained not only from the case studied, but also can be obtained from all those who know the case well. In this study, the case study conducted on Telkom University about World-Class University. The research data collected through direct observation, interviews with various sources both from Telkom University and outside parties related to the research, as well as various related information in the form of notes and documents, obtained both offline and online.

\section{Indonesian Higher Educations Position}

From the statistical data taken from Forlap Dikti (22 April 2018) the number of higher educations in Indonesia is 4.632, consisting of 420 state-owned higher educations, and 4.210 private higher educations. We then can conclude that the number of private higher educations is ten times higher from the total number of tertiary educational institutions in Indonesia. The number of students can be seen from the Table 1.1.The data shows that the number of the higher educations is fantastic. Private universities have 3.301.817students or almost two times higher than the number of students studying in state university (2.196.195).

Table 1.1

\begin{tabular}{|l|l|}
\hline Type & Number of Student \\
\hline State-Owned Higher Educations & 2.196 .195 \\
\hline Private Higher Educations & 3.301 .817 \\
\hline Total & 5.498 .012 \\
\hline
\end{tabular}

Source: Forlap Dikti (accessed on 22 April 2018)

As has been previously explained that no one can really point whether a university is a World-Class University, but through the world university ranking system at least we can know from 4,632 higher educations in Indonesia, where are the universities position compared to other universities in the world or in the same continent. Nowadays, there are several institutions assessing the excellence of universities in the world, such as Shanghai Jia Tong University (SJTU); Times Higher Education (THE); Quacquarelly Symonds (QS); Webometric. Each of them has certain criteria as the indicators. In this paper we use only one of them, which is Quacquarelly Symonds (QS). Quacquarelly Symonds (QS) uses QS World University Rankings, covering fivecriteria, namely: 'academic peer review'or the analysis from academician communities; 'recruiter review', almost the same as the academic peer; 'faculty student ratio' that assess the lecture quality; 'citation per faculty 'or academic publication conducted by each faculty cited in international scale; and 'international orientation', assessed from the percentages of international students and staff. Sourced from Quacquarelly Symonds (QS) World University Ranking 2018 list, there are only nine universities in Indonesia that are included in the World Top 1000 ranking, they are as listed in the table below. Also, from the same source, only three of them mentioned in the Asia Top 100 ranking, they are Universitas Indonesia (Rank 54), Institut Teknologi Bandung (Rank 65), and Universit as GadjahMada (Rank 85).

Table 1.2

\begin{tabular}{|c|c|c|}
\hline No. & World Rank & University \\
\hline 1 & 277 & Universitas Indonesia \\
\hline 2 & 331 & InstitutTeknologi Bandung \\
\hline 3 & $401-410$ & UniversitasGadjahMada \\
\hline 4 & $701-750$ & UniversitasAirlangga \\
\hline 5 & $751-800$ & InstitutPertanian Bogor \\
\hline 6 & \multirow{4}{*}{$801-1000$} & UniversitasDiponegoro \\
\hline 7 & & $\begin{array}{l}\text { InstitutTeknologiSepul } \\
\text { uh November }\end{array}$ \\
\hline 8 & & UniversitasMuhammadiyah Surakarta \\
\hline 9 & & UniversitasBrawijaya \\
\hline
\end{tabular}


From the tables above we can conclude that even though Indonesia has many higher educational institutes or universities, in fact those that achieve world ranking are still low, not to mention that among these universities there is not even one listed on the World Top 100 rank. It implies that it is not easy for them to reach the reputation of World-Class University (WCU). Sure such achievement requires not only hard work, financial support, and management, but also extremely serious commitment. Aside from Indonesian universities world rank we can see in table 1.2, we can also see Indonesian universities position among the countries in South East Asia or in Asia.

Table 1.3

\begin{tabular}{|c|c|c|c|c|}
\hline \multirow[b]{2}{*}{ No } & \multirow[b]{2}{*}{ Country } & \multicolumn{3}{|c|}{ Number of University } \\
\hline & & $\begin{array}{ll}\text { World } & \text { Top } \\
1000 & \\
\end{array}$ & $\begin{array}{ll}\text { World } & \text { Top } \\
100 & \\
\end{array}$ & $\begin{array}{ll}\text { Asia } & \text { Top } \\
100 & \\
\end{array}$ \\
\hline 1 & Singapore & 3 & 2 & 3 \\
\hline 2 & Malaysia & 9 & 0 & 5 \\
\hline 3 & Indonesia & 9 & $\mathbf{0}$ & 3 \\
\hline 4 & Thailand & 8 & 0 & 3 \\
\hline 5 & Philippines & 4 & 0 & 2 \\
\hline 6 & $\begin{array}{l}\text { Brunei } \\
\text { Darussalam }\end{array}$ & 1 & 0 & 0 \\
\hline 7 & Vietnam & 0 & 0 & 0 \\
\hline 8 & Laos & 0 & 0 & 0 \\
\hline 9 & Myanmar & 0 & 0 & 0 \\
\hline 10 & Cambodia & 0 & 0 & 0 \\
\hline
\end{tabular}

Source: Quacquarelly Symonds (accessed on 22 April 2018)

As Indonesia is one of the developing countries, comparing the universities there with the ones in developed countries will be too much. On the smallest comparative scale, we can compare Indonesia's universities position with the ones in the other developing countries within ASEAN. As it can be seen from Table 1.3, although ASEAN has one developed country (Singapore), but compared to other ASEAN countries, the position of Indonesian universities is better, along with Malaysia and Thailand, where four other countries in ASEAN (Vietnam, Laos, Myanmar, and Cambodia) do not even have a university that goes into the World Top 1000 list.Compared to other developing countries in Asia, Indonesia's position is also quite good, even though it is still far behind China and India. Out of 48 developing countries in Asia, only 22 countries manage their university to be listed on the World Top 1000 rank, but still not all of these universities get into the Asia Top 100 rankings, the details can be seen in table 1.4 below. 
Table 1.4

\begin{tabular}{|l|l|l|l|l|}
\hline \multirow{2}{*}{ No } & \multirow{2}{*}{ Country } & \multicolumn{2}{|l|}{ Number of University } \\
\cline { 3 - 5 } & & $\begin{array}{l}\text { World Top } \\
\mathbf{1 0 0 0}\end{array}$ & $\begin{array}{l}\text { World Top } \\
\mathbf{1 0 0}\end{array}$ & $\begin{array}{l}\text { Asia Top } \\
\mathbf{1 0 0}\end{array}$ \\
\hline 1 & China & 39 & 6 & 23 \\
\hline 2 & India & 20 & 0 & 9 \\
\hline 3 & Malaysia & 9 & 0 & 5 \\
\hline $\mathbf{4}$ & Indonesia & $\mathbf{9}$ & $\mathbf{0}$ & $\mathbf{3}$ \\
\hline 5 & Thailand & 8 & 0 & 3 \\
\hline 6 & Kazakhstan & 8 & 0 & 0 \\
\hline 7 & Saudi Arabia & 7 & 0 & 0 \\
\hline 8 & Pakistan & 6 & 0 & 1 \\
\hline 9 & UAE & 6 & 0 & 0 \\
\hline 10 & Iran & 5 & 0 & 0 \\
\hline 11 & Filipina & 4 & 0 & 2 \\
\hline 12 & Lebanon & 3 & 0 & 0 \\
\hline 13 & Bahrain & 2 & 0 & 0 \\
\hline 14 & Iraq & 2 & 0 & 0 \\
\hline 15 & Jordan & 2 & 0 & 0 \\
\hline 16 & Bangladesh & 1 & 0 & 0 \\
\hline & Brunei & & & \\
17 & Darussalam & 1 & 0 & 0 \\
\hline 18 & Palestine & 1 & 0 & 0 \\
\hline 19 & Sri Lanka & 1 & 0 & 0 \\
\hline 20 & Kuwait & 1 & 0 & 0 \\
\hline 21 & Oman & 1 & 0 & 0 \\
\hline 22 & Qatar & 1 & 0 & \\
\hline
\end{tabular}

Source: Quacquarelly Symonds (accessed on 8 May 2018)

\section{Challenges Faces by Indonesian Higher Educations}

Technology and human civilization are growing rapidly, therefore without a good human resource, a country can experience setbacks. This is a challenge that must be solved by every country in the world. To get good quality human resources, every country is competing to improve its education standard. In this case, it cannot be denied that universities play an important role in providing good quality human resources, because college graduates are expected to have sufficient skills to be able to directly enter various fields of work in a competitive global world these days. But in reality, the management of universities in Indonesia is still lacking in supporting Indonesian universities to be a World-Class University. In this paper, there are two challenges which will be the main focus discussion.The challenges concerning political and cultural variation within Indonesian higher education sector itself and Indonesian government as regulations and policies maker that used as guidelines in the education sector.

\section{a. The higher education's management in Indonesia is highly bureaucratic}

The higher education management in Indonesia is still highly bureaucratic by using the methods, procedures, and accountability applicable in government bureaucracy. It can decrease the agility in higher education management, and therefore it decreases competition nature. It is different from the higher education management implemented by developed countries, in which it is carried out professionally within the autonomous higher education with less intervention from the government bureaucracy. Management of state-owned universities with the concept of subsidy budget from the government is considered less effective, because it makes the burden of government is more severe. To support universities in order to compete and excel at the global level, requires a lot of money and cannot be charged entirely to the government budget. Government subsidies will "spoil" state universities, so even though state universities have some government standards to be achieved, they will not be challenged to achieve excellence beyond those standards and to improve competitiveness, as they are also limited by the government subsidies. Governments in some developed countries, never wanting to be burdened by the cost of higher education, because higher education investment is more regarded as an individual investment than public 
investment (Suryadi, 2014). The higher educations in Indonesia do not manage in corporation which emphasizes independence and professionalism. Though UU BHP has been repealed, the concept of PTN-bh as the substitute, as what has been arranged in UUPT No. 12 year 2012 through clauses related to PT Badan Layanan Umum (BLU) and PTN BerbadanHukum (PTN-bh) still cannot encourage higher educations to become a global players.

\section{b.Discrimination government's policy treatment towards private universities}

The number of private colleges is almost nine times higher compared to state colleges, so does the number of the students is also greater than the students of state colleges. Unfortunately, the government seems to be more concerns about the state-owned collages than the private ones, for examples in the aspect of infrastructure fulfillment, placement of the lecturers, a rule imposing sanction policy, and research funding. For example, the requirement of accreditation points of the National Accreditation Board of Higher Education (BAN-PT), its preparation, and complicated reporting, are considered hard for the private higher educations, so the government should take the side of the private university as a facilitator, as well as to conduct assistance and mentoring. However, private colleges founded independently and autonomously are believed to be able to fund itself and do not urgently need those supports. Government regulation and the concept of policy issued in UUPT No.12 year 2012 and others, is found more concerned about state-owned higher educations.

Government institution that administers the college such as Badan Layanan Umum (BLU) and PTN BerbadanHukum (PTN-bh) also seems to support the state-owned universities more to be independent so that they can compete globally and become a World-Class University. This kind of treatment towards private universities have to be put to an end, because basically many private universities have been implementing their university management professionally, independently and autonomously toward World-Class University (such as Telkom University), but they still need some support from the governments especially as the regulation maker.

\section{A Case Study from Telkom University-Bandung}

In order to implement the role map of Telkom University in the national and world context, since 2013 Telkom University has decided the long-term vision in the next 25 years ahead (2038) to be a 'Global Entrepreneurial University. This vision of Telkom University is a contribution and becomes a part of our national vision to bea developed country in 2025. Figure 1.1 below describes a long-term roadmap Telkom University to gain the vision of 2038.

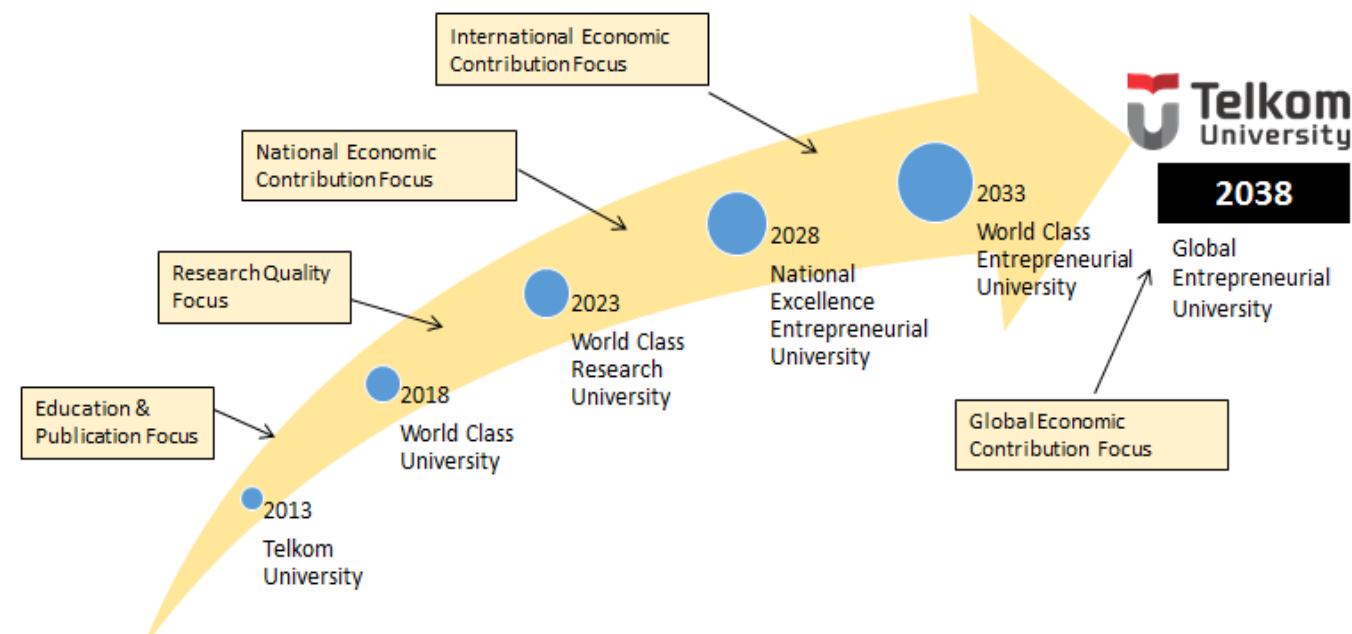

Figure 1.1 Roadmap of Telkom University from 2013 to 2038

For the first period of the long-term roadmap of Telkom University, there is a Strategic Plans (Renstra) which shows the targets to achieve by Telkom University as can be seen in Figure 1.2 below. 


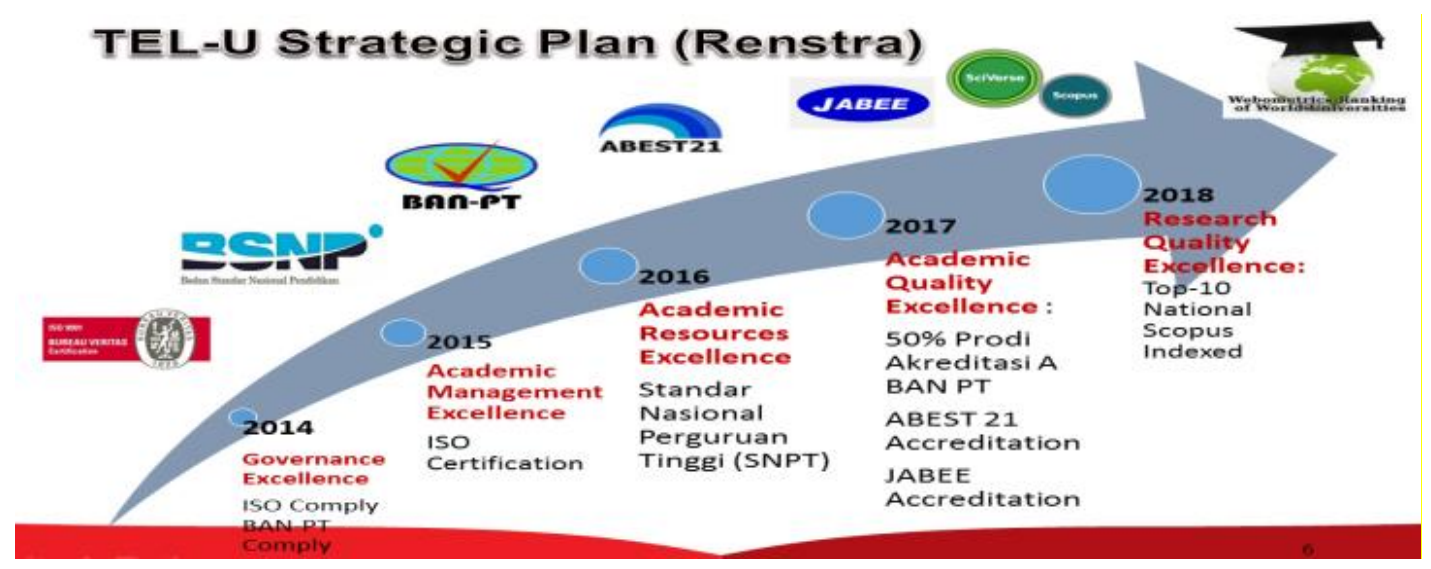

Figure 1.2 Telkom University's Strategic Plan from 2014 to 2018

This strategic plan for 2014-2018 periods has been passed. However, even though Telkom University has not made it into the World Top 1000 rankings, Telkom University has made many achievements in accordance with the strategic plan. Here are some of the achievements by Telkom University that can be seen from its official website (www.telkomuniversity.ac.id):

1. Since December 2016, Telkom University has been accredited "A", meaning an outstanding institution, assessed by BAN PT (the National Accreditation Board of Higher Education Indonesia). This outstanding accreditation was granted to 48 universities only, among 4632 higher education institutions in Indonesia. Beside recognized as the best institution, recently, almost $70 \%$ of all programs offered by the university have achieved the highest grade of accreditation by BAN PT.

2. In 2017, Telkom University received 5 stars from QS Star, in categories of teaching, employability, innovation, and inclusiveness. Other International accreditation boards such as IABEE and ABEST 21 (Japan) also recognized some departments, while ASIC (Accreditation Services of International Colleges $\mathrm{UK}$ ) is assessing 6 programs in the three faculties.

3. In 2018, Telkom University is ranked 24th for best university in Indonesia, and ranked 19th for university in Indonesia with the most Scopus publication.

To gain the objective of being World-Class University in 2018, Telkom University has designed the steps that need to be achieved each year. Though World-Class University is yet to be achieved, having identified the criteria targeted in 2018 makes all the components and potentials emphasized are emphasized for them. Several internal potentials also support the objectives, such as management improvement, the increase of human capital, structure and infrastructure, and the increase of the quantity and quality of higher education's three pillars.From this illustration, we can take some lessons:

- Vision, mission, objectives and strategic plan from a visionary leader enhance the possibility of a university in aiming high.

- Telkom University is a sample of private university which is organized professionally and independently. It is capable of making various strategic decisions as long as its vision and long-term goal are concerned.

- Government will reassure universities toward World-Class University. They do not only focus on state-owned universities, in fact there are many private universities that can be assisted to be a World-Class University.

- For private universities, the goal to be World-Class Universityis a strategy to elevate their brand, student intake, and internal improvement, however on the other side, government will use it to boost government objectives to place Indonesian universities and their graduates in the global level.

\section{Recommendation Plan}

Based on two issues that are the main focus of this paper, namely the management of universities in Indonesia and the unfair treatment of the Indonesian government towards state-owned and private universities, and also taking lessons from the case study at Telkom University, the author recommends two completion plans that are expected to be implemented by both of these parties to work together in creating World-Class University in Indonesia. 


\section{The revision of university management in Indonesia}

In order to minimize bureaucracy in university management, the procedures should be done professionally, independently, autonomously with less intervention from the government. The universities have to be autonomous and independent in finance and investment without taking too much of the government's budget and subsidy. The subsidy should be allocated effectively on investment which gives contribution to the competitiveness improvement, such as research grants multiply and the increase of foreign cooperation. This is not an easy task, but it is worth trying, as in developed countries where the higher educations managed with the concept of "higher education as industry", where the concept prioritizes independence and professionalism, so as not to burden the government, it can contribute to the government in the form of foreign exchange instead. For state-owned universities, the first step that can be done is to bring up the policy to change the state-owned universities into legal entities. As legal entities, universities have the autonomy and independence to manage their own assets and finances. As for private universities, they can start by participating in an international standard university governance training program, to assist in the opening of international cooperation, as well as to learn about the creation of rules and regulations that can encourage private universities to achieve World-Class University.

In addition to converting higher education's governance to become autonomous, each university should also have a long-term roadmap program along with detailed programs and targets that must be achieved each year to reach World-Class University.

\section{The Equality of policy treatment on state-owned and private universities}

The great number of private universities indirectly shows that they have given significant contribution to the nation and the university themselves.

The number of private university students which is twice than the state collage cannot be underestimated. Thus it is necessary to consider the same treatment for the private universities in term of regulations, policies and infrastructure development grants.

As a recommendation, government can equate the treatment between state-owned and private higher educations by utilizing national and international ranking systems without distinguishing whether the university is a stateowned or private university. In this system the government can give special predicate to universities in certain rank, like in the graduation predicate such as cum laude, etc. Here are examples of systems that Indonesian government can consider:

1. World Top 100 Rank

We know that the closest ranking for a university to be considered as a World-Class University is The World Top 100 Rank. If there are universities in Indonesia that enter this rank, that university can be given a 'brilliant' predicate. Unfortunately until now there is no university in Indonesia who reached this rank.

2. World Rank 101 to 500

This level contains universities with world rankings of 101 to 500. The predicate that can be given is 'excellent'. Currently, there are three universities in Indonesia that enter this level, as can be seen in Table 1.2.

3. World Rank 501 to 1000

This level contains universities with world rankings of 501 to 1000 . The predicate that can be given is 'great'. Currently, there are six universities in Indonesia that enter this level, as can also be seen in Table 1.2.

4. Indonesia's Accreditation A

This level contains universities in Indonesia that have an A of national accreditation, but not yet ranked in the World Top 1000. No predicate is given at this level. Currently the university in Indonesia with an A of national accreditation is 70 universities, minus nine universities in World Top 1000 then there are 61 universities in this level.

5. Indonesia's Accreditation B

This level contains universities in Indonesia that have a B of national accreditation. No predicate is given at this level. Currently the university in Indonesia with a B of national accreditation is 558 universities.

6. Indonesia's Accreditation C

This level contains universities in Indonesia that have a $\mathrm{C}$ of national accreditation. No predicate is given at this level. Currently the university in Indonesia with a $\mathrm{C}$ of national accreditation is 961 universities.

At each of the above levels, the universities will get different privileges, where universities with the 'brilliant' predicate will get more rights and obligations than the ones with the 'excellent'predicate, and so on. At a glance this seems to give more benefits to the private university, since the private university is originally has been 42 
independently and autonomously established, they will develop more with government support in this system. However, if considered further, this system can be a driving force for other private universities to follow in the footsteps of private universities with good rank in Indonesia, as well as to encourage the competitiveness of state universities so as not to lose from private universities. In other words, all universities in Indonesia will be competing to become World-Class University. But then, this system would be impossible if all the funds needed to run it came only from government subsidies, therefore it would be helpful if universities in Indonesia could use the concept of 'higher education as industry' first, so that the funds to run this system would not only come from the government but may also come from other sources or sponsors.

\section{Conclusion}

From the analysis mentioned above, it can be concluded that:

- The number of private universities in Indonesia is ten times the number of state universities, while the number of private university students is almost two times higher than that of the state universities. Yet, there are only nine universities that are able to be in the 1000 world ranking and only three universities which are in 100 Asia ranking.

- The small number of World-Class University in Indonesia is caused by several factors, such as the bureaucratic university management, the funding which still counts on the subsidy from the government, the management which is unprofessional and dependent. Not to mention the policy discrimination to the state universities. For the improvement, the universities in Indonesia have to be more independent and autonomous, and the government should give support and treat all the universities equally.

- Basically, there are many promising private universities that can be supported to become a World-Class University, for instance Telkom University.

From the analysis above, it can be recommended as follow:

- Changing the pattern of university management with the concept of "higher education as industry" as in developed countries. Conducting benchmark and building international cooperation, as well as make a longterm plan for each university to achieve World-Class University.

- Creating regulation, system, or rule that can build conducive education atmosphere and encourage the universities in Indonesia to become a World-Class University in order to provide better human capital in Indonesia.

\section{References}

Altbach, Peter G. (2003). 'The Costs and Benefits of World Class Universities', International Higher Education, vol. 33., pp. 5- 8.

Becker, Gary S. (1962). 'Investment in Human Capital: A Theoretical Analysis, The Journal of Political Economy, vol 70, Issue 5, pp. $9-49$

BadanAkreditasiNasionalPerguruanTinggi (2018). "DirektoriHasilAkreditasiInstitusi", accessed on 11 May 2018, available online athttps://banpt.or.id/direktori/institusi/pencarian_institusi.

KebijakanPembanguanKarakterBangsaPemerintah RI Year 2010 - 2015

Khoiriyah, Ruisa (2018). "100 UniversitasTerbaik di Indonesia Tahun 2018, DaftarTerbaru yangPerluKamuTahu", accessed 8 May 2018, available online at: https://www.halomoney.co.id/blog/100-universitas-terbaik-diindonesia-tahun-2018.

Marginson, Simon (2013). 'Different Roads to a Shared Goal: Political and Cultural Variation in World-Class Universities', in Qi Wang, Ying Cheng \&NianCai Liu (eds), Building World-Class Universities: Different Approaches to a Shared Goal, Rotterdam: Sense Publishers, pp 13-44.

Moleong, Lexy J. (2004).MetodePenelitianKualitatif. Bandung: RemajaRosdakarya.RencanaStrategis (Renstra) Telkom University-Bandung

Rizal, Achmad (2017). "PeringkatTelkom University di Scopus BulanJuli2017”, accessed on 12 May 2018, available online at https://achmadrizal.staff.telkomuniversity.ac.id/peringkat-telkom-university-di-scopus-bulan-juli$2017 /$.

Salmi, Jamil (2009).The Challenge of Establishing World Class Universities, Washington D.C.: The World Bank.

Suryadi, Ace. (2014). Pendidikan Indonesia Menuju 2025. Bandung: RemajaRosdakarya.

Suryadi, Ace.(2011). Pendidikan, PengembanganSumberDayaManusia, dan Pembangunan. Bandung: Widya Aksara Press.

UU No. 20 Tahun 2003 tentangSistemPendidikanNasional.

Undang -UndangRI No: 12 Tahun 2012 tentangPendidikanTinggi 